\title{
'UN FIUME PICCOLISSIMO DI QUEL MARE IMMENSO' UNIVERSALISM, NAVIGATION AND THE RETHINKING OF THE MEDITERRANEAN IN CAMPANELLA
}

\author{
JEAN-PAUL DE LUCCA \\ UNIVERSITY OF MALTA
}

\begin{abstract}
This contribution offers an intertextual reading of Tommaso Campanella's early political writings and his utopia, The City of the Sun, with a view of bringing to the fore his stance on the radical shift in early modern maritime geopolitics. Campanella's proposals for the establishment of world governance were informed by his enthusiasm for inventions such as the navigational compass, and by his emphasis on maritime prowess as a necessary condition for creating a universal monarchy. The dialogical and poetic character of The City of the Sun, and the choice of its imaginary interlocutors, may suggest an interpretation of Campanella's utopia as a distinctively Mediterranean encounter between the 'old World' and the 'New World'. The transfer of knowledge and communication thus emerge as crucial lynchpins in Campanella's project for universal reform and unity.
\end{abstract}

\section{Key Words}

Mediterranean, navigation, The City of the Sun, Tommaso Campanella (15681639).

\section{Navigating the Mediterranean and Beyond}

The town of Stilo in Calabria, where Tommaso Campanella was born on 5 September $1568,{ }^{1}$ sits at the feet of the Monte Consolino, facing the river Stilaro that leads to the Ionian Sea. In one of his early poems, written around the time of

1 For an introduction to Campanella's life, thought and works, see Germana Ernst, Tommaso Campanella. The Book and the Body of Nature, Dordrecht: Springer, 2010. 
the failed rebellion of 1599 which would cost him almost thirty years of imprisonment, the philosopher attributed the foundation of his hometown to the fact that the original inhabitants had sought a strategic refuge from Hannibal's invasion:

\author{
Monte di Magna Grecia, ch'al gran seme \\ non misto a gente unqua a virtù rubella, \\ in Stilo, patria mia, nel tempo ch'ella \\ siede nel lido ove l'Ionio freme, \\ doni albergo secur, sì che non teme \\ d'Annibale la gente cruda e fella, \\ che per tutto scorrea dalle castella, \\ predando i mari e le campagne insieme $[. . .]^{2}$
}

Back then, the Ionian coast of Calabria, like many other parts of the Mediterranean, was a frequent target of pirates and Ottoman incursions. As a child, Giovan Domenico Campanella (who took the name Tommaso upon joining the Dominican Order) would have heard many stories of ships sailing menacingly close to the shores and settlements ravaged by pirates. The Calabrian perspective of the Mediterranean Sea is well documented in the literature of the years preceding and following the battle of Lepanto. Like many of his compatriots, the young Campanella was particularly sensitive to the constant threat of maritime assault. However, the Mediterranean Sea represents an ostensibly minor concern in the vision of universal reform and world governance that underpins his political works. As Fournel puts it, the Mediterranean perspective is too narrow for his universalistic intentions. ${ }^{3}$ Campanella's political thought follows the method of his epistemology: it begins with the observation of particular phenomena, which then transcends into theoretical abstraction, universalisation or speculation that includes also the realm of possibility (or utopianism). His view of the Mediterranean extends into a broader concern with navigation and maritime politics, and, especially, its reconfiguration in light of the discoveries of the oceans to its west and east. In this context, Campanella may be considered to be one of the first to articulate the radical shift in maritime relations that was unfolding as a result of contact with the 'new world'. ${ }^{4}$

2 Tommaso Campanella, 'Sovra il Monte di Stilo', in Poesie, edited by F. Giancotti, Milano: Bompiani, 2013, p. 308.

3 Jean-Louis Fournel, La cité du soleil et les territoires des hommes. Le savoir du monde chez Campanella, Paris: Albin Michel, 2012, p. 261.

4 On Campanella and the new world, see Jean-Louis Fournel, 'Nuovo Mondo', in Eugenio Canone and Germana Ernst (eds.), Enciclopedia Bruniana \& Campanelliana, vol. 1, Pisa-Roma: Serra, 2006, pp. 291-303; and 'Mare', in vol. 2 (2010), pp. 256-270. 
Campanella's outlook was informed by both the popular imaginary of the perils of the sea and the widely held view of the sea having been created by God to separate and divide lands and people. In his overarching vision of unity and universality, however, the sea becomes a space of communication and a means for establishing the universal monarchy. In ancient times, navigation had facilitated the cultural connection between his native land - then part of Magna Graecia - and the hub of classical civilization on the other side of the Ionian Sea. Campanella's Calabrian pride is evident in the preface to his first published work, Philosophia sensibus demonstrata (1591), a treatise defending Bernardino Telesio against his Aristotelian critics, where he argues passionately that far from being home to uncouth brutes (as Telesio's adversary Giacomo Antonio Marta had implied), Calabria counted many philosophers and inventors among its inhabitants. ${ }^{5} \mathrm{He}$ also recalls the ancient legend according to which Noah's descendant Ashkenaz settled in the fertile area of Reggio Calabria after the biblical flood. ${ }^{6}$ The Mediterranean Sea, he writes elsewhere, owes its origin to the water entering through the strait of Gibraltar after the flood, which then moved eastwards until it reached Cyprus and Tyre. ${ }^{7}$ In his works on natural philosophy, then, he also explains why great rivers such as the Ganges and the Nile, though similar in depth to the Mediterranean, are not saltwater. ${ }^{8}$

The Mediterranean Sea and its surrounding regions remained a geopolitical space of contention among the major powers in early modernity. The Italian peninsula, in particular, was a strategic theatre of influence and alliances. Campanella was not indifferent to the hardships caused by the iron-handedness of the Spanish rule over the kingdom of Naples, yet his early political works were

5 Tommaso Campanella, Philosophia sensibus demonstrata, Neapoli: apud Horatium Salvianum, 1591, pp. 12-13: 'Omnis quoque disciplina apud Calabros, et tota scientia hominum et quae nunc versatur in scholis inde originem sumpsit. [...] Haec enim dicta sunt, ut sciat Sciolus et latrantes, nostros non fuisse brutos, sicut ipse est, et taceo ne alios offendam propter ipsum'. Campanella is addressing the Neapolitan jurist Giacomo Antonio Marta, author of Pugnaculum Aristotelis adversus principia Bernardini Telesii.

$6 \quad$ Ibid., p. 12: 'sciat quod omnium fere Regionum optima et antiquissima est Calabria, quae post diluvium incoepit habitari obi loci fertilitatem ab Aschenam nepote Noè apud Reghium'.

7 Tommaso Campanella, Epilogo magno (Fisiologia italiana), edited by Carmelo Ottaviano, Roma: Reale Accademia d'Italia, 1939, p. 253: 'et l'Europa dall'occidente verso Borea, divisa dall'Affrica per il Mar Mediterraneo, il qual entrò a tempo di gran diluvio per lo stretto di Gibilterra, et scorse verso levante sino al Tirio et Ciprio Mare, che fa col Mar Rosso l'Affrica penisola, et indi verso il settentrione sino alla foce del Tanà [...]'.

8 Ibid., p. 257: 'I grandissimi fiumi, come I'Indo e 'l Gange, il Tigre, il Nilo, il Po et Dannubio, l'Oregliana, il Maragnone, la Platta et altri assai, che arrivano a sessanta leghe [di larghezza] et a profondità quasi simili al Mare Mediterraneo, bisogna dire che nascano anch'essi di terra conversa in vapore et ispessata, o di terra liquida ma non bruciata, perché non sono salse né grosse né amare come il mare'. The origins of the sea and its salinity are discussed at length, in polemic with Aristotle, in Tommaso Campanella, Quaestiones physiologiae, in Philosophia realis, Parisiis: ex typographia D. Houssaye, 1637, pp. 179-211. 
distinctly philo-hispanic and accentuated the southern Italian diffidence towards France in light of the Franco-Turkish alliance between Francis I and Suleiman. He would later disavow Spain and turn towards Louis XIII and Richelieu with renewed hope in the establishment of a universal monarchy, ${ }^{9}$ but in the 1590 s he was still concerned with the 'dubious danger' posed by the fact that some Italian princes preferred an alliance with the Habsburgs while others were inclined to forge political bonds with France. In his Discorsi ai principi d'Italia, written between 1594 and $1595,{ }^{10}$ Campanella makes it clear that it was only the Habsburgs ('Casa d'Austria') and the Ottomans ('Casa Ottomana') who could realistically aspire to achieve a universal monarchy. The text presents a series of arguments aimed at convincing Italian princes to put aside their differences and to unite under the Spanish empire and the spiritual leadership of the papacy, for no other power could better guarantee their safety and prosperity. The divisions among Christian princes, Campanella writes, only serve to expose them 'to the mouth of the great Turkish dragon'. ${ }^{11}$ In his view, the Turkish Empire, or 'the Grand Turk', represents a tyrannical form of government founded on fear and whose actions prove harmful to Christians and Muslims alike. ${ }^{12}$ In his assessment of the strengths and weaknesses of the two competing European great powers,$^{13}$ the crucial role of the mastery of navigation and maritime politics in building and maintaining empires emerges as one of the key elements that could tilt the balance in favour of Spain. Without explicating the popular parallel between Alexander the Great and the Turkish Empire, Campanella instead draws a comparison between Alexander and Spain, noting that the latter held under its

9 In October 1634 Campanella fled from Rome to Paris, where he died on 21 May 1639.

10 Tommaso Campanella, Discorsi ai principi d'Italia, edited by Luigi Firpo, Torino: Chiantore, 1945. This edition is based on the only extant manuscript, which is a reworked version completed in 1607; see also Luigi Firpo, Bibliografia degli scritti di Tommaso Campanella, Torino: Bona, 1940, pp. 130-131.

11 Ibid., p. 109: 'e questo andar noi debilitando le forze di Cristiani è un manifesto esponersi alla bocca del gran drago turco'.

12 One of the ambiguities in Campanella's thought concerns the link between the Ottoman Empire and Islam. In many cases he is careful to distinguish the empire as a political entity from the religious dimension, arguing that the tyrannical monarch ought to be defeated by military force, while religious differences ought to be settled through theological debate and preaching. In other instances, he combines his criticism of Islam and its founder with attacks directed at the Turkish Empire. And while in The City of the Sun Muhammad is placed alongside other great religious founders, elsewhere Campanella includes him among false prophets and religious tyrants.

13 Tommaso Campanella, Discorsi ai principi d'Italia, p. 99: 'In Europa Casa d'Austria e Casa Ottomana aspirano alla somma delle cose umane e stan quasi in bilancia'. 
dominion almost the entire ocean, "while the ancients had conquered only the whole Mediterranean, which is like a tiny river of that immense sea which wraps together the entire world and is so vast and deep'. ${ }^{14}$

This consideration constitutes Campanella's most explicit early statement of the radical shift in maritime politics by the end of the sixteenth century. The oceans were now no longer a mysterious unknown space, but an opening towards faraway lands and peoples which anyone who aspired to establish a universal monarchy had to navigate and dominate. While the Turkish Empire was militarily stronger than the House of Austria, the latter's undisputed superiority in the vast seas on either side of the Mediterranean was the real game changer in the radically reconfigured geopolitics. The Spanish control over the Mediterranean region remained important insofar as it was necessary for securing and guaranteeing European unity as a precondition for the establishment of a universal monarchy, which is precisely why the Italian princes are exhorted to join the Habsburg Empire in the Discorsi ai Principi d'Italia. As shown in many of his other works, however, Campanella already perceived an even greater threat to unity in the 'old world' resulting from the politicoreligious divide that emerged with the rise of Lutheranism and the Protestant Reformation. His universalistic aspirations are carefully and complexly articulated along three different fronts: pacification and reconciliation in northern Europe, resistance to the Ottoman advance through the Mediterranean and the Balkans, and the dominion of the oceans ('la signoria del mare') as a means of including the 'new world' in the project of universal governance. As far as the Mediterranean Sea was concerned, it remained the space in which the Ottoman advance into Europe had to be stalled and possibly backtracked, but it was certainly no longer the main theatre of world politics.

These ideas, and especially the importance of navigation, are further expressed in Monarchia di Spagna. Although, as has been noted above, Campanella had departed completely from his philo-hispanic stance by the 1630s, this early work is ostensibly the one that enjoyed the widest circulation thanks to a German translation published in the 1620 s and several posthumous Latin editions printed from 1640 onwards under the title De monarchia hispanica. It was only in recent decades that Germana Ernst published the original text, purged of many unidentified interpolations taken from Giovanni Botero which had made their

14 Ibid., p. 118: 'Aggiungi poscia il dominio di quasi tutto l'oceano, che è inestimabile, poiché gli antichi appena tutto il Mediterraneo ottennero, il quale è come un fiume piccolissimo di quel mare immenso, che cinge tutto il mondo ed è tanto spazioso e profondo'. 
way into all the older editions. ${ }^{15}$ Campanella completed this work in the months immediately after his condemnation to life imprisonment, more or less at the same time as he was writing The City of the Sun, although Ernst has convincingly argued that the original redaction of the text dates back to $1595,{ }^{16}$ thus making it contemporaneous with the Discorsi ai Principi d'Italia. A chapter that shows evidence of reworking is Chapter 15 , on the military. ${ }^{17}$ The later version ends with the crucial statement that "he who was lord of the sea, was also lord of the land'. ${ }^{18}$

\section{The Dominion of the Sea, Magnets and Wooden Floating Cities}

In Campanella's assessment, the dominion over the seas functions as a necessary requirement for dominating over lands and peoples. ${ }^{19}$ His idea of dominion (dominium) is to be understood in the context of his metaphysics of the three primalities of being, namely power, wisdom and love or charity (the opposites of which are tyranny, sophistry and hypocrisy). ${ }^{20}$ In the second chapter of his treatise on politics, he defines dominion as an extension of power, which may be exercised either according to, or against, right (sive iure sive iniuria) ${ }^{21}$ Kingdoms and empires, then, combine right and dominion: without power (dominion) they are a mere philosophical precept, without right they constitute a tyrannical power, and without charity they are nothing but frivolous. ${ }^{22}$ In the application of his principles of natural philosophy to the political sphere, Campanella identifies the reason and purpose of government and law with the return to the original unity of all things. His universalism, as manifested in his projects for a universal

15 Tommaso Campanella, Monarchia di Spagna, in Monarchie d'Espagne et Monarchie de France, edited by Germana Ernst, with a French translation by Nathalie Fabry and Serge Waldbaum, Paris: PUF, 1997.

16 Tommaso Campanella, La Monarchia di Spagna (redazione giovanile), edited by Germana Ernst, Napoli: Istituto Italiano per gli Studi Filosofici, 1989.

17 'Il modello della vera milizia' in Tommaso Campanella, Monarchia di Spagna; 'Della milizia' in Tommaso Campanella, La Monarchia di Spagna (redazione giovanile).

18 Tommaso Campanella, Monarchia di Spagna, p. 150: 'La milizia del mare, a cui son buoni i Genovesi e Portoghesi e Olandesi, è la più necessaria, perché chi fu <buon guerriero del mare, fu anco della terra preditore, e chi è> signore del mare, fu anche della terra'.

19 It is interesting to read Campanella's views alongside Carl Schmitt's idea of world history as the history of wars waged between maritime and land powers; see Carl Schmitt, Land and Sea: A World-Historical Meditation. Translated by Samuel Garrett Zeitlin, edited and with Introductions by Russell A. Berman and Samuel Garrett Zeitlin, Candor, NY: Telos Press Publishing, 2015.

20 For an overview see Germana Ernst, Tommaso Campanella. The Book and the Body of Nature, pp. 205207.

21 Tommaso Campanella, De politica, edited with an Italian translation by Antimo Cesaro, Napoli: Alfredo Guida Editore, 2001, p. 53.

22 Ibid., p. 57: 'Regnum enim est participium iuris et dominii [...] Absque dominatu enim est philosophicum preaceptum, absque iure tyrannica potestas, absque charitate, insulsa facultas'. 
monarchy (as opposed to tyranny), must be understood in this context. Moreover, his political philosophy is explicitly formulated to counter Machiavelli's theory of the ragion di stato which, in Campanella's view, promotes the exact opposite end of ruling through division and fear. The 'real' ragion di stato, for him, has unity and peace as its ultimate end. ${ }^{23}$

Campanella, whose universalism was deeply influenced by his familiarity with prophecy and astrology, saw in the discovery of the New World the opening of the possibility to move closer to the ideal of unity. In the Discorsi ai Principi d'Italia, he suggests that Providence had provided the Habsburgs with 'two marvellous instruments' that would allow them to keep the barbarians at bay and to navigate through winds and waves without the guidance of the stars, two things that had seemed impossible before. These two inventions were the magnetic compass [calamita] which God inspired Flavio, an Italian from Amalfi, to invent; and the harquebas against the barbarians' ${ }^{24}$ The name and very existence of Flavio Gioia was already disputed in Campanella's time: in De magnete (1600), for instance, William Gilbert recalls that the humanist historian Flavio Biondo (1392-1463) had reported that the people of Amalfi boasted that they were taught how to build the compass by their 'fellow citizen Giovanni [sic] Goia' around the year $1300 .{ }^{25}$ Gilbert acknowledges that ancient sources and various other arguments suggest that the compass was invented by the Chinese and brought to Europe by Marco Polo around the year 1260. Yet, he states that he did not wish to deprive the Amalfitans of the honour of having invented 'the most beneficial instrument for the human race', given that anyway it was thanks to them that the compass was 'produced and distributed in the Mediterranean'. ${ }^{26}$ In his commentaries of

23 For a succint exposition of this concept, which is not free from ambiguity, see Germana Ernst, 'ragion di stato', in Enciclopedia Bruniana \& Campanelliana, vol. 1, pp. 317-329.

24 Tommaso Campanella, Discorsi ai principi d'Italia, p. 123: 'E perché era impossibilie penetrar con sí poca gente, come è la Spagnuola, fra tanti barbari innumerabili e di poter navigar l'oceano immenso senza stelle e senza settentrione fra venti ignoti, Dio trovò due instrumenti maravigliosi: la calamita per il mare inspirata a Flavio, italiano di Amalfi, e li archibugi contra i barbari, inspirati ad un tedesco'.

25 William Gilbert, De magnete, magneticisque corporibus, et de magno magnete tellure, Londini: ex Petrus Short, 1600, p. 4: 'Flavius Blondus Melphitanos haud perperam gloriari prodit, edocti a cive quodam Iohanne Goia, anno post natum Christum Millesimo trecentesimo'. Gilbert confuses Amalfi with Melfi when he writes: 'Oppidum illud in regno Neapolitano, non procul a Salerno, iuxta promontorium Minervae situm, cuius principatu Carolus quintus Andream Doream, magnum illum Classicum ducem, propter egregiam navatam operam donavit'. While Amalfi is indeed close to Salerno, Charles V made Doria feudatory lord of Melfi (not Amalfi) in 1531. Had there been such an association between Amalfi and Doria, a key figure in securing Spain's predominance in the Mediterranean and one of his heroes, Campanella would have surely highlighted it.

26 Ibid.: 'Atque illa quidem pyxide, nihil unquam umanis excogitatum artibus, humano generi profuisse magis, constat: inventam tamen ante ab aliis, et in marinis artibus admissam, ex veteribus scriptis, et quibusdam argumetis et coniecturis existimant nonnulli. Scientia Nauticae 
Lucretius' works (1511), the Bolognese scholar Giambattista Pio had repeated Flavio Biondo's account in such a way that readers could have inferred that the magnetic compass was invented in Amalfi by Flavio, rather than that by Flavio's account the magnetic compass was invented in Amalfi. ${ }^{27}$ It is very likely that Campanella, who was very familiar with Lucretius' De rerum natura, relied on Pio as his source. While there is no way of knowing whether he was aware of the doubts surrounding the figure of Flavio, it is clear that the attribution of such an important invention to 'an Italian from Amalfi' fit perfectly the point he wanted to make in his Discorsi ai Principi d'Italia, as it was a notable example of the ability of the Italians to serve the Spanish cause. Moreover, as Gilbert would do a few years later, Campanella stresses the importance of the invention of the magnetic compass in light of Spanish maritime expansion: 'the Mediterranean could have been navigated without the magnet, but not so their ocean' ${ }^{28}$ The calamita was, as it were, a further confirmation that the world had outgrown its Mediterranean confines, as did the Calabrian philosopher's worldview.

Much of what has been said so far features in a suggestive passage in Campanella's The City of the Sun, the imaginary dialogue between a Knight Hospitaller and his guest, a Genoese captain of Colombus' ship. After listening carefully to the captain's account of the beliefs and customs of the city's inhabitants, the Hospitaller expresses the view (held by Campanella himself) that:

[Hosp.:] 'If these people who follow only the law of nature are so near to Christianity, which adds nothing but the sacraments to the law of nature, I conclude from your report that Christianity is the true law and that, once its abuses have been corrected, it will become mistress of the world'. ${ }^{29}$

The above English translation, based on the 1602 Italian manuscript, does not capture fully the allusion to signoria and dominium when it renders 'signora del mondo' as 'mistress of the world'. ${ }^{30}$ In Campanella's fundamental vision of the

pyxidulae traducta videtur in Italiam, per Paulum Venetum [i.e. Marco Polo], qui circa annum MCCLX apud Chinas artem pyxidis didicit. Nolim tamen Melphitanos tanto honore privare, quod ab iis in mari mediterraneo primum vulgariter fabricata fuerit'.

27 See Chiara Frugoni, Medioevo sul naso: occhiali, bottoni e altre invenzioni medievali, Bari: Laterza, 2004, p. 142.

28 Tommaso Campanella, Discorsi ai principi d'Italia, p. 123: 'il Mediterraneo senza calamita si navigava, ma il loro oceano non così'.

29 Tommaso Campanella, La Città del Sole: Dialogo Poetico / The City of the Sun: A Poetical Dialogue. Translated into English by Daniel J. Donno, Berkeley, CA: University of California Press, 1981, p. 121.

30 Both Latin editions, published during Campanella's lifetime and under his supervision, read 'Domina ... in toto Terrarum orbe'; see Tommaso Campanella, Civitas Solis, in Philosophia realis, Francofurti: impensis G. Tampachii, 1623, p. 460; and Parisiis: ex typographia D. Houssaye, 1637, 
return of everything to its original nature, natural law and natural religion converge in a reformed Christianity and serve as the basis for political life in a universal monarchy founded on right and dominion, i.e. on the wise and just exercise of power directed towards establishing and maintaining peace and unity. To stress this point, the Hospitaller makes a second observation:

'I also conclude that for this reason the Spaniards discovered the rest of the world so as to unite it all under one law, even though Columbus, your fellow Genoese, was its first discoverer. [...] I see, moreover, that we know not what we do but are instruments of God. Thanks to their hunger for gold, the Spaniards go about discovering new countries, but God has a higher end in mind'. ${ }^{31}$

As he does in the Discorsi ai Principi d'Italia, and, though less explicitly, in Monarchia di Spagna, Campanella acknowledges that although the Spaniards' real intentions might not have been pious and their actions not always correct, their empire served as the physical means through which to achieve a higher goal, which the papacy (according to his vision of a renewed and truly catholic Church) would lead morally and spiritually. The Genoese captain's response to the Hospitaller's remark completes Campanella's own vision and aspirations for the century that was unfolding, as well as his enthusiasm for the spread of knowledge and new inventions:

[Gen.:] 'Oh, if you only knew what they deduce from astrology and from the prophets - our own as well as the Hebrews' and those of other people - about our present century, which has produced more history in a hundred years than the whole world did in the preceding four thousand! More books have been written in the last century than in the previous five thousand years. And what they say about our stupendous inventions - the compass, the printing press, the harquebus mighty signs of the imminent union of the world ....32

Earlier in the dialogue, the Genoese captain reports that the Solarians use the art of navigation, which is held in high esteem among them ('dignificatur valde apud eos'), as a means of establishing communication with other people and learning from them:

[Gen.:] 'Navigation is also highly regarded, and they have vessels that move without wind roar, while others are propelled by both wind and oar. They understand the stars, the ebb and the flow of tides, and they travel to learn about

p. 166. Moreover, in both editions, the sentence ends with the added phrase: 'ut praeclariores Theologi docent et spirant' ('as the most renowned theologians teach and hope').

31 Tommaso Campanella, The City of the Sun, p. 121.

32 Ibid. 
other countries and people. To no one do they bring harm. Without provocation they will not fight. They are convinced that the whole world will eventually bring itself to live as they do. Yet they are forever exploring to learn if others live better than they do'.33

These words were written in 1602, while Campanella was also developing the idea that 'he who was lord of the sea, was also lord of the land'. ${ }^{34}$ If dominion is understood as the exercise of power in conjunction with right, then such dominion over the sea denotes the aim of bringing improvement and unity through communication and learning. It is significant that at this point in his utopia - which is but a 'poetic' synthesis of his thought - Campanella highlights the pacific nature of the Solarians by introducing two important qualifications: their navigation brings no harm, and they will only fight if they are provoked. The signoria del mare, or dominion over the sea, then, is subject to a fundamental restriction that evokes the principle that war may only be waged legitimately if the casus belli, or provocation, is proven. Moreover, in the context of the practices employed by the Spanish colonizers of the Americas - a major theme in sixteenth- and seventeenth-century legal and political thought, which Campanella followed and commented upon ${ }^{35}-$, it is especially poignant that he should specify that navigation, which he saw as a means for establishing dominion, ought not to inflict harm and injury. It is in such contexts that Campanella's utopian work cannot be properly understood without referencing his other writings, be they more theoretical or more practical, and vice-versa.

Navigation features prominently as the title and subject matter of the concluding chapter of Monarchia di Spagna. ${ }^{36}$ These pages, like the rest of the book, are a mix of insightful analyses, moral indications, and original proposals, coupled with a few odd overenthusiastic pronouncements and an accentuated realism of an ostensibly Machiavellian kind. Campanella suggests that the King of Spain requires 'a thousand ships, and wise and courageous men, to achieve dominion over the New World, Africa, the islands, the coasts of Asia, Calicut, China and Japan'. The King should value people more highly than he values metals such as gold and silver, for his earlier experience with England, France

33 Ibid., p. 87. The term translated here as 'navigation' is 'marinaria' in the Italian manuscript and 'ars nautica' in both Latin editions. A parallel may be drawn between the last sentence and the verse from the Book of Daniel (12:4) which Francis Bacon, author of New Atlantis, would place on the frontispiece of his Novum Organum Scientiarum (1620): 'multi pertransibunt et augebitur scientia'.

34 See note 18 above.

35 Much of the debate revolved around the concept of ius gentium, see Jean-Paul De Lucca, 'Ius gentium', in Enciclopedia Bruniana \& Campanelliana, vol. 2, pp. 243-256.

36 Chapter 32 ('Della navigazione') is common to both the early redaction and the final version, with very minor variations between the two. 
and the Low Countries showed that it is useless for Spain to have 'more and better metals but less and worse men'. ${ }^{37}$ Campanella suggests that the King of Spain should also give greater consideration to men than to money when looting places, for the former are a safer and nobler treasure than the latter. Moreover, the King of Spain should enter into agreements with other maritime forces such as Portugal and Genoa: he should allow them to carry on their conquests and retain the loot as long as Spain would be granted right over the land and children under the age of seven, so that they may be sent to nautical schools set up by the king. ${ }^{38} \mathrm{He}$ further suggests that the Genoese should be rewarded handsomely, lest they shift their allegiance to the Turkish Empire and acquire lands for themselves rather than for Spain. Securing loyalty through friendship, rather than by armed force, is a more effective way of dealing with the Genoese and 'hispanicising the world'. ${ }^{39}$ Those who acquire lands on behalf of Spain should be afforded not only monetary rewards but also honour and fame: they should be allowed to enter the city triumphantly in Roman style, have statues erected in their honour and have the cities they conquered painted on triumphal arches. Likewise, the rulers of the lands they would have conquered should be honoured and co-opted into the empire. The King should know, Campanella says, that he needs nothing more than loyal subjects, as well as a wise legislator like Lycurgus or Solon: 'there are more [wise legislators] today than there were in their days, but they are envied more and known less, since the ability to understand things has been restricted to a set of vile rules'. ${ }^{40}$ Besides territorial expansion through maritime dominion, the establishment of a universal monarchy under Spanish control depended heavily on the acquisition and advancement of knowledge. The King of Spain was to send competent Flemish and German mathematicians all over the world to measure the ebb and flow of stars, the depths of the seas, and tidal movements, because 'this knowledge will make you master ['padrone'] of the sea and the land and men, and will magnify your empire more than anything else you could imagine'. ${ }^{41}$

37 Tommaso Campanella, Monarchia di Spagna, p. 356.

38 Cf. Tommaso Campanella, The City of the Sun, p. 77: 'The conquered cities [...] receive Solarian officials and a garrison from the City of the Sun and proceed to model their institutions after those of that city which is henceforth their guide. They also send their children to study in the City of the Sun and pay nothing for their maintenance'.

39 Monarchia, p. 358: 'e così si spagnolarebbe il mondo'. See also p. 234: ‘[The King of Spain should use the Genoese] for navigation'.

40 Ibid.: 'ha bisogno d'un gran savio come Licurgo e Solone, delli quali più ne sono oggi che a loro tempo, ma più invidiati e meno conosciuti, per essersi ristretto l'intendimento delle cose sotto a certe regole vili ecc'.

${ }^{41}$ Ibid.: 'questo sapere ti farà padrone del mare e della terra e degli uomini e illustrerà l'imperio più che ogni cosa che si possa imaginare di far grande il Re'. 
Campanella further proposes that the King should build ports, arsenals, ships and galleys wherever he conquered, and make use of sailors he would have trained at his own expense. To this end, the young philosopher's strongest proposal was that the King should establish navigational schools in which youngsters would be taught how to build ships and galleys, read navigational charts and observe the stars. He suggests that it would be especially useful to set up such 'seminaries' on the Mediterranean islands of Sicily and Sardegna, as well as on the Canary Islands and in the Philippines. More drastically, the children of heretics, Turks and occupiers of the Flanders and Africa should be snatched away and trained in such seminaries for sailors, or in similar ones for soldiers and farmers (though not as slaves).

The idea of establishing nautical schools was first mentioned in a work known as the Discorsi universali sul governo ecclesiastico (c. 1593), written originally a year or two prior to the Discorsi ai Principi d'Italia and the first redaction of the Monarchia di Spagna. Here Campanella suggests that in the activities against the infidels, it would suffice for the Pope to establish [...] seminaries of religious soldiers that benefit us and terrify the enemy, in order to achieve continuous victories, as the Maltese do'. ${ }^{42}$ In the Monarchia di Spagna, then, he proposes the setting of two orders of 'knights of the sea, like those of Malta, and establish their captains in two distinct colleges in Spain, one for the East and the other for the West'. ${ }^{43}$ Such knights were to learn the art of navigation, spend a probationary period as novices and then vow to sail the seas for the greatest good of Spain; they would be noblemen and made captains of the sea. These schools and colleges would create a strong and well-trained navy ('armata in mare'), which neither the Turk, nor the Persian nor anyone else could ever hope to match. ${ }^{44}$

Campanella's suggestions are formulated with the specific intention of establishing and consolidating constant contact between the two hemispheres, as a way of achieving the goal of uniting the Spanish Empire. The ocean was no longer an unknown and mysterious space, and ships would serve as "many wooden cities floating in the sea, toing and froing between them and us, carrying merchandise and goods from one part to the other, always going around the world'. ${ }^{45}$

42 Tommaso Campanella, Discorsi universali del governo ecclesiastico per far una gregge e un pastore, in Opere di Giordano Bruno e Tommaso Campanella, edited by Augusto Guzzo and Romano Amerio, Milano: Ricciardi, 1956, pp. 1148-1149.

43 Tommaso Campanella, Monarchia di Spagna, p. 360.

44 Ibid., p. 362.

45 Ibid., p. 358: 'Ma sopra tutto per mantener[e il Nuovo Mondo] con noi unito, è necessario far tante cittadi in mare di legname, che sempre vadano e vengano da loro a noi, con portar mercanzie e traffichi dall'una all'altra parte, e girar sempre il mondo'. 
The references to islands, to cities as topoi of transfer and communication, to the Hospitaller Knights of Malta, and to the Genoese in this concluding chapter of the Monarchia di Spagna make for highly significant intertextual links with The City of the Sun.

\section{Poetic Dialogue Between Old and New}

Campanella began writing The City of the Sun shortly after being handed a life sentence for heresy and high treason on account of his alleged role in the attempted uprising of Stilo against the Spanish authorities. It circulated in manuscript until its first publication in Frankfurt, in 1623, as an appendix to his treatise on politics in the quadripartite Philosophia realis. It was later republished in Paris (1637), with some minor variations. The fact that the Italian manuscript and the final Latin edition present no substantial differences, bar a few significant additions concerning astrology, shows that the shift in the author's own allegiance had not changed the essence of his ideal of reform and unity. This ideal, as enunciated in The City of the Sun, both complements and contrasts with the pragmatic means to achieve it, which are put forward in the manner of counsel in the explicitly political works mentioned above.

As its subtitles indicate, The City of the Sun is at once an 'Idea of a philosophical republic' and 'a poetical dialogue'. ${ }^{46}$ It is a philosophical 'idea' or 'form' because it lays down the rational principles required for the construction of the civitas, not only as a physical location (with a carefully planned infrastructure and with buildings and walls that reflect the structure of the cosmos) but also as the manifestation of rational legislation and government aimed at establishing and maintaining the good life. Laws create the city in both its physical form and its moral character, as well as a space for the acquisition and transfer of knowledge. ${ }^{47}$ Understood in this sense, the 'wooden cities' floating on water may be seen as extensions of the civitas.

The City of the Sun is 'poetic' insofar as such an ideal form of legislation and organization cannot rely on existing examples. Its character is essentially pedagogic and exemplary, as Campanella explains in his treatise on poetics:

46 'Idea reipublicae philosophicae' and 'Dialogo poetico'/'Dialogus poeticus'.

47 The appeal for wise legislators and rulers, such as Lycurgus and Solon, is a common theme in Renaissance and early modern utopias inspired above all by Plutarch's Lives. Cf. Tommaso Campanella, The City of the Sun, p. 117: 'The admit that there is great corruption in the world and that men govern themselves foolishly, not according to reason. They say that the good suffer while the wicked rule, though such rulers are not really happy because there is selfannihilation in pretending to be what you are not - that is, in pretending to be a king, a good and wise man, when you are not so in fact'. 
'Fiction and imagination are not ends in themselves, but by accident, when real examples are lacking. Their use is legitimate even when one wants to explain philosophical concepts. The poet's art and purpose lies not in imitating and pretending, but rather in imitating in order to represent, in representing in order to appeal and teach, in teaching and appealing in order to promote law, virtues and the good life'. ${ }^{48}$

The imago poetica captures the very spirit of poiesis as an act of creation and transformation in the realm of possibility. Both the city (civitas) and the cities in the sea (cittadi in mare) are, therefore, topoi of ideal transformations sustained by the movement of people and goods, the exploration of the good life and the communication and transfer of knowledge. For Campanella, changing geopolitical realities pave the way for what Fournel, borrowing and adapting J.K. Wright's term, has rightly identified as geosophy: 'a reading of the world and its history as a narration, simultaneously, of its past, present and future, with each temporality weighing on the other', in a continuous interplay between territory and knowledge. ${ }^{49}$

Campanella's use of the dialogical form goes beyond being an overtly Socratic exercise written in Plato's fashion. The careful choice of the two interlocutors and the context in which the fictitious dialogue takes place offer significant interpretive possibilities in light of what has been said earlier about Campanella's views on navigation, the discovery of the New World, and his universalist outlook on world governance. More specifically, the interpretation being suggested here sheds light on how the Calabrian philosopher might have thought of the Mediterranean beyond its geographical reconfiguration as 'a tiny river in that immense sea', set against the broader background that has been traced above, a synthesis of which appears in The City of the Sun.

In the Latin editions of Civitas Solis, the interlocutors are introduced as 'Hospitalarius Magnus et Nautarum gubernator Genuensis Hospes'. This slight variation from the Italian version's 'Ospitalario e Genovese nochiero del Colombo' places a clearer focus on hospitality and the host-guest relationship (hospes means both 'guest' and 'host' in Latin) that underpins the dialogue, which is, in turn, the manner in which knowledge is shared and acquired. On account of their different roles as hospites, the two interlocutors share the ethical foundation

48 Tommaso Campanella, Poetica, in Philosophia rationalis, Parisiis: apud Ioannem Du Bray, 1638, p. 117: 'Itaque palam est, non per se requiri imitationem et fabulam in poëmate, sed per accidens, ubi desunt exempla vera; quod etiam Philosophicas res declarando fieri licet. Poëtae igitur finis et ars non est imitari et fingere, sed imitatur ut representet, repraesentat ut afficiat et doceat; docet et afficit ut suadeat, legem, virtutes et beatam vitam'.

49 Jean-Louis Fournel, La cité du soleil et les territoires des hommes. Le savoir du monde chez Campanella, pp. 30-31. 
of friendship as a precondition for a meaningful dialogue to take place. ${ }^{50}$ This reaffirms Campanella's strongly held view that unity and peace could only be achieved when rational dialogue replaces the use of force and the sophistry of the grammarians. ${ }^{51}$

The dialogue is an encounter between two figures who, as has been shown above, represent two important Mediterranean maritime powers which, in Campanella's eyes, represented important features of the efforts towards world unity. The Hospitaller was a 'knight of the sea' belonging to a religious order under papal jurisdiction, whose members belonged to noble families from all over Europe. The Grand Master of the Order was at once the sovereign prince of an island located at the centre of the Mediterranean and a religious figure equivalent in rank to a cardinal..$^{52}$ The Genoese captain had navigated the oceans and visited the City of the Sun located on Taprobana, the classical name of the island of Sri Lanka. The dialogue between the two, presumably in Malta or in some other Mediterranean location, takes place upon the captain's return from sailing around the world and describes the life of the Solarians as a return to the natural origins of life and society. The clear distinction between the roles of the inquisitive host and the narrating guest gives the dialogue a clear structure of an encounter between imaginary representatives of the 'old' and the 'new' worlds, which is accentuated by a few but significant comparisons between the Solarians' practices and how things are done 'among us'.53

The Hospitaller embodies the curiosity in the 'old continent' about the New World separated by the oceans, while the Genoese satisfies (at least partially) his curiosity by describing in detail what he had witnessed and learnt during his navigation. The Mediterranean, though certainly reconfigured, thus became a contact point for dialogue and transfer of knowledge which could open up possibilities not only for further contact but, perhaps even more importantly, for inspiring what Campanella considered to be much needed reforms in Europe. For although his political thought has sometimes been labelled as 'Eurocentric' - and it is indeed difficult to imagine it being otherwise -, his approach is clearly that of extending philosophical reflection in parallel with the eastward and westward

50 The ancient Greek concept of hospitality, xenia ( $\xi_{\varepsilon v i ́ \alpha}$ ), is a key theme in Homer's Iliad and Odyssey. Also, the early institutions set up by the Knights Hospitallers were known as xenodochia.

51 For example, this is made explicit in his so-called missiological treatise known by the title Reminiscent et convertuntur ad Dominum universi fines terrae, which includes a series of legations to the rulers and religious leaders of the world and the proposal of a general council of religions.

52 See Jean-Paul De Lucca, 'Prophetic Representation and Political Allegorisation: The Hospitaller in Campanella's The City of the Sun', in Bruniana \& Campanelliana, 15:2 (2009), pp. 387-405. The City of the Sun's chief official, the Metaphysician, or Hoh, was the supreme religious and civic leader.

53 Tommaso Campanella, The City of the Sun, pp. 35, 41, 47 and passim. 
extension of the knowledge of the world (geosophy). His early appeals for cooperation and unity in the Mediterranean and in Europe thus appear as the first but crucial step in a far-ranging universal project. Campanella's worldview moves outwards from the Mediterranean - the epicentre of the classical world to the oceans and faraway lands not only, and perhaps not so much, in political terms as dominio and signoria, but especially and more significantly as a dialogo poetico: the opening of possibilities for the creation of unity through the acquisition of knowledge and communication, paving the way for what he called the renovazion del secolo, or the renewal and transformation of the world.

\section{Bibliography}

Canone, Eugenio, and Ernst, Germana (eds.), Enciclopedia Bruniana e Campanelliana, Pisa-Roma: Fabrizio Serra Editore, vol. 1: 2006; vol. 2: 2010.

De Lucca, Jean-Paul, 'Prophetic Representation and Political Allegorisation: The Hospitaller in Campanella's The City of the Sun', in Bruniana \& Campanelliana, 15:2 (2009), pp. 387-405.

Ernst, Germana, Tommaso Campanella. The Book and the Body of Nature, Dordrecht: Springer, 2010.

Firpo, Luigi, Bibliografia degli scritti di Tommaso Campanella, Torino: Bona, 1940.

Fournel, Jean-Louis, La cité du soleil et les territoires des hommes. Le savoir du monde chez Campanella, Paris: Albin Michel, 2012.

Frugoni, Chiara, Medioevo sul naso: occhiali, bottoni e altre invenzioni medievali, Bari: Laterza, 2004.

Gilbert, William, De magnete, magneticisque corporibus, et de magno magnete tellure, Londini: excudebat Petrus Short, 1600.

Schmitt, Carl, Land and Sea: A World-Historical Meditation, translated by Samuel G. Zeitlin, edited and with Introductions by Russell A. Berman and Samuel G. Zeitlin, Candor, NY: Telos Press Publishing, 2015.

Tommaso Campanella, Philosophia sensibus demonstrata, Neapoli: apud Horatium Salvianum, 1591. 
, Philosophia realis, Francofurti: impensis G. Tampachii, 1623; Parisiis: ex typographia D. Houssaye, 1637.

, Philosophia rationalis, Parisiis: apud Ioannem Du Bray, 1638.

, Discorsi ai principi d'Italia, edited by Luigi Firpo, Torino: Chiantore: 1945.

Discorsi universali del governo ecclesiastico per far una gregge e un pastore, in Opere di Giordano Bruno e Tommaso Campanella, edited by Augusto Guzzo and Romano Amerio, Milano: Ricciardi, 1956.

La Città del Sole: Dialogo Poetico / The City of the Sun: A Poetical Dialogue. Translated by Daniel J. Donno, Berkeley, CA: University of California Press, 1981.

, La Monarchia di Spagna (redazione giovanile), edited by Germana Ernst, Napoli: Istituto Italiano per gli Studi Filosofici, 1989.

, Monarchie d'Espagne et Monarchie de France, edited by Germana Ernst, with a French translation by Nathalie Fabry and Serge Waldbaum, Paris: PUF, 1997.

, De politica. Italian Translation by Antimo Cesaro, Napoli: Alfredo Guida Editore, 2001.

, Poesie, edited by Francesco Giancotti, Milano: Bompiani, 2013. 